\title{
BOVINE-TESTIS CELLS FOR ROUTINE ISOLATION OF RESPIRATORY SYNCYTIAL VIRUS FROM INFANTS
}

\author{
E. O. CAul*, J. W. Jacobs† $†$, and Suzanne K. R. Clarke* \\ Public Health Laboratory, Bristol BS2 8EL*, and Royal Veterinary College, \\ London NW1 OTU†
}

VIRUS isolation is still the most important method for the diagnosis of respiratory syncytial (RS) virus infections in hospitalised infants. For most laboratories the culture system used is either "Bristol" HeLa (HL) cells (Holzel et al., 1965; Stott et al., 1967; Sturdy, McQuillin and Gardner, 1969; Jacobs et al., 1971) or HEp-2 cells (Suto et al., 1965; Aitkin, Moffatt and Sutherland, 1967; Beem, 1969; Sturdy et al., 1969). Some workers have suggested that other primate cells might be more suitable, such as diploid human lung (Anderson and Beem, 1966), continuous human amnion (Berglund and Stråhlmann, 1967; Young and Matthews, 1969), and continuous monkey kidney (Berglund, Vihma and Wickström, 1965).

Although it was known that the Long strain of RS virus could be adapted to grow in bovine kidney cells (Coates, Forsyth and Chanock, 1966) other human isolates of RS virus grew poorly in them (Gharpure, Wright and Chanock, 1969). When studying human and bovine isolates of RS virus at the Royal Veterinary College it was noted that both grew very well in cultures of foetal bovine testis (BT) and so it was decided to compare directly the efficacy of these cells with that of HL cells for the primary isolation of RS virus from infants.

\section{MATERIALS AND METHODS}

Cell cultures. The BT cells were derived from the testes of a 4-month Friesian calf foetus by trypsinisation at $36^{\circ} \mathrm{C}$. They were used in the tests described at the 18 th to 25 th passages. They were grown as monolayers in stationary tubes at $35^{\circ} \mathrm{C}$ in Eagle's Minimum Essential Medium with $0.25 \%$ lactalbumin hydrolysate, $6.5 \%$ foetal calf serum, $0.09 \%$ sodium bicarbonate, and antibiotics (streptomycin, penicillin and amphotericin B). For maintenance the serum content was reduced to $2 \%$ and the sodium bicarbonate increased to $0 \cdot 22 \%$, and yeast extract $(0.05 \%)$ was included.

"Bristol " HL cells (Peacock and Clarke, 1961) were grown as monolayers in stationary tubes at $35^{\circ} \mathrm{C}$. The cells were in current use by the Bristol Public Health Laboratory for the isolation of RS virus. They were grown in Earle's Saline with $0.25 \%$ lactalbumin hydrolysate, $8 \%(\mathrm{v} / \mathrm{v})$ inactivated rabbit serum, $0.12 \%$ sodium bicarbonate, and antibiotics (streptomycin, polymyxin-B sulphate and nystatin). For maintenance the serum was reduced to $4 \%$ and the sodium bicarbonate increased to $0 \cdot 22 \%$. It was necessary to use different maintenance media for the two cultures, as they had not been adapted to a common maintenance medium.

Specimens. Between January and April 1973, 110 nasopharyngeal secretion samples were obtained by suction from 55 infants ( 23 aged 0-3 months, 18 aged 4-6 months, 11 aged 7-11 months, and three aged 13 or 14 months) admitted to hospital in Bristol with acute respiratory disease. Each sample was diluted with a small amount of phosphatebuffered saline and a portion was removed for routine virus isolation. The residue was mixed with $1 \mathrm{ml} \mathrm{HL}$ growth medium containing $10 \%$ dimethyl sulphoxide (DMSO) and stored at $-60^{\circ} \mathrm{C}$ after rapid freezing in an alcohol bath placed in the deep-freeze. After periods ranging from 2 to 12 weeks, all the aspirates were thawed rapidly in a waterbath

Received 24 Sept. 1973; accepted 14 Nov. 1973.

$\ddagger$ Present address: North East London Polytechnic, London E15 4LZ.

J. MED. MICROBIOL.- VOL. 7 (1974) 
at $37^{\circ} \mathrm{C}$ and $0 \cdot 2-\mathrm{ml}$ amounts were inoculated simultaneously into tubes of $\mathrm{HL}$ and BT cells. The medium was changed next day and thereafter twice a week and the cultures were examined daily for 28 days for a cytopathic effect (CPE). RS virus isolates were identified by the indirect immunofluorescence technique.

Ten of the specimens caused contamination in one or other cell culture. Only 82 of the remaining 100 specimens were tested fully in HL cells before freezing.

\section{RESULTS}

The BT cells grew readily producing monolayers of mixed fibroblastic and epithelioid cells. Because of very rapid multiplication, cells from the first five passages would have been

TABLE I

Time taken for cytopathic effect (CPE) of respiratory syncytial virus to became visible in cell cultures

\begin{tabular}{ccc}
\hline $\begin{array}{c}\text { Duration of } \\
\text { incubation } \\
\text { (days) }\end{array}$ & $\begin{array}{c}\text { Number of virus isolations as judged by } \\
\text { appearance of CPE in }\end{array}$ \\
\cline { 2 - 3 } & BT cells & HL cells \\
$0-1$ & 0 & 0 \\
$2-3$ & 4 & 0 \\
$4-5$ & 15 & 3 \\
$6-7$ & 14 & 6 \\
$8-9$ & 5 & 7 \\
$10-11$ & 2 & 4 \\
$12-13$ & 3 & 5 \\
$14-15$ & 2 & 2 \\
$16-17$ & 0 & 0 \\
$18-19$ & 0 & 0 \\
$20-21$ & 0 & 2 \\
$22-23$ & 0 & 32 \\
\hline Total isolations & 45 & \\
\hline
\end{tabular}

$\mathrm{BT}=$ Bovine testis; $\mathrm{HL}=\mathrm{HeLa}$.

unsuitable for use. The CPE of respiratory syncytial virus was very easy to detect in BT cells. At first, isolated syncytia were seen. These increased in number and size until the whole cell sheet was involved. Later the syncytia became detached and the cell sheet disintegrated.

From the 100 frozen uncontaminated specimens, 46 isolations of RS virus were made, 45 in BT cells and 32 in HL cells. Thus only one of these samples failed to give a positive result in BT cells, whereas 14 failed to do so in $\mathrm{HL}$ cells. The increased sensitivity of the BT cells is also reflected in the length of incubation required before a CPE was first recognised (table I). The average period was 6.5 days for BT cells and 10.6 days for HL cells.

The results for the 82 specimens which were tested in HL cells before freezing are shown in table II. Eight of the 11 isolations made from frozen specimens in BT cells but not HL cells had earlier been made in HL cells before freezing of the specimens. Six isolations were made before but not after the specimens were frozen.

\section{Discussion}

The RS-virus isolation rate of $43 \%(35 / 82)$ in HL-cell cultures before the freezing of the specimens compares favourably with the rates reported when similar populations were 
studied by the same cell-culture method. Thus Clarke et al. (1964) reported 27\%, Holzel et al. (1965) $29 \%$ and Jacobs et al. (1971) $30 \%$. Although cough swabs and not nasopharyngeal secretions were used in these earlier studies, the use of secretions would be expected to increase the isolation rate by only about $5 \%$ (Sturdy et al., 1969). We concluded that the HL cells used in our comparison were probably of maximal sensitivity.

Although it is well known that specimens for RS isolation should preferably not be frozen (Beem et al., 1960) several workers have found that fairly good virus recovery can be achieved if the specimen is snap-frozen and held at low temperature in a protective medium (Hambling, 1964; Suto et al., 1965; Law and Hull, 1968), but the results of direct comparisons have not been reported before. Our results (table II) confirm the observations of Beem et al. (1960).

BT cells were superior to HL cells for the isolation of RS virus from frozen nasopharyngeal secretions, as regards the number of isolates and the rate of production of CPE. There

TABLE II

Isolation of respiratory syncytial virus from 82 specimens before and after freezing

\begin{tabular}{|c|c|c|c|}
\hline \multirow{3}{*}{$\begin{array}{l}\text { Number of } \\
\text { specimens }\end{array}$} & \multicolumn{3}{|c|}{ Isolation of virus in } \\
\hline & \multicolumn{2}{|c|}{ HeLa cells } & \multirow{2}{*}{$\begin{array}{l}\text { bovine testis cell } \\
\text { after freezing } \\
\text { of specimen }\end{array}$} \\
\hline & $\begin{array}{l}\text { before freezing } \\
\text { of specimen }\end{array}$ & $\begin{array}{l}\text { after freezing } \\
\text { of specimen }\end{array}$ & \\
\hline 21 & + & + & + \\
\hline 8 & + & - & + \\
\hline 6 & + & - & - \\
\hline 1 & - & + & + \\
\hline 3 & - & - & + \\
\hline 43 & - & - & - \\
\hline
\end{tabular}

$+=\mathbf{R S}$ virus isolated $--=\mathbf{R S}$ virus not isolated

was no evidence that the additonal isolations made in BT cells differed from those in HL cells, because most of the additional isolations had also been made in HL cells before the specimens were frozen.

BT cells had several other advantages over HL cells. The cultures remained as a monolayer throughout the observation period, unlike the HL cells, which tended to overgrow and pile up. The BT cells were diploid with the typical telocentric bovine-chromosome configuration and number $(2 \mathrm{n}: 60)$, with no abnormal forms at the 38 th passage. Thus BT cells are likely to maintain their sensitivity for at least this number of passages. HL cells, being heteroploid with rapid growth, sometimes develop mutants resistant to RS virus. This is illustrated by the variation in sensitivity of different lines of "Bristol " HL cells. Bovine testes can readily be obtained from abattoir foetuses or at castration of young bull calves. Variations in sensitivity to RS virus of seven such testes cultured at the Royal Veterinary College have been insignificant. In another testis culture, fibroblasts became predominant; the CPE was much more difficult to see and did not progress. Cell suspensions maintain viability at $-180^{\circ} \mathrm{C}$ in $10 \%$ DMSO.

\section{SUMmaRY}

One hundred specimens of nasopharyngeal secretion were collected from infants with acute respiratory disease and stored at $-60^{\circ} \mathrm{C}$ before inoculation into tube cultures of bovine testis (BT) and HeLa (HL) cells. Of a total of 46 specimens which yielded respiratory syncytial virus, 45 did so in BT cells but only 32 in HL cells. The mean incubation time before a cytopathic effect was first detected was 6.5 days for BT cells and 10.6 days for HL cells. 
We would like to thank Dr J. M. B. Edwards of the Central Public Health Laboratory, Colindale, for the supply of reagents for immunofluorescence, Dr H. R. Cayton and Dr N. Edington for helpful advice, Dr A. P. C. H. Roome for the collection of aspirates, and the paediatricians at the Bristol Royal Hospital for Sick Children and Southmead Hospital, Bristol. Part of this work was supported by a grant from the Agricultural Research Council.

\section{REFERENCES}

Artkin, C. J. D., Mofrat, M. A. J. AND Sutherland, J. A. W. 1967. Respiratory illness and viral infection in an Edinburgh nursery. J. Hyg., Camb., 65, 25.

ANDERson, J. M. AND BeEM, M. O. 1966. Use of human diploid cell cultures for primary isolation of respiratory syncytial virus. Proc. Soc. exp. Biol. Med., 121, 205.

BeEM, M. O. 1969. Acute respiratory illness in nursery school children: a longitudinal study of the occurrence of illness and respiratory viruses. Am. J. Epidem., 90, 30.

Beem, M. O., Wright, F. H., Hamre, D., Egerer, R. AND Oehme, M. 1960. Association of chimpanzee coryza agent with acute respiratory disease in children. New Engl. J. Med., 263, 523.

Berglund, B. AND StRÄhlmanN, C.-H. 1967. Respiratory syncytial virus infections in hospitalised children: evaluation of virus isolation and complement fixation techniques in the virological diagnosis: clinical and epidemiological characteristics. Acta paediat. scand., 56, 269.

BERGLUND, B., VIHMA, L. AND WiCKSTRÖM, J. 1965. Respiratory syncytial virus studies on children hospitalized during an outbreak of respiratory illness in Finland. $A m . J$. Epidem., 81, 271.

Clarke, S. K. R., Corner, B. D., Gambier, D. M., Macrae, J. and Peacock, D. B. 1964. Viruses associated with the acute respiratory infections. Br. med.J., 1, 1536.

COATES, H. V., ForsYTH, B. R. AND CHANOCK, R. M. 1966. Biophysical studies of respiratory syncytial virus. I. Density of respiratory syncytial virus and associated complementfixing antigens in a cesium chloride density gradient. J. Bact., 91, 1263.

Gharpure, M: A., Wright, P. F. AND Chanock, R. M. 1969. Temperature-sensitive mutants of respiratory syncytial virus. J. Virol., 3, 414.

Hambling, M. H. 1964. Survival of the respiratory syncytial virus during storage under various conditions. Br.J. exp. Path., 45, 647.

Holzel, A., Parker, L., Patterson, W. H., Cartmel, D., White, L. L. R., Purdy, R. ThOMPSON, K. M. AND TOBIN, J. O'H. 1965. Virus isolations from throats of children admitted to hospital with respiratory and other diseases, Manchester 1962-4. Br. med.J., 1, 614.

Jacobs, J. W., Peacock, D. B., Corner, B. D., Caul, E. O. and Clarke, S. K. R. 1971. Respiratory syncytial and other viruses associated with respiratory disease in infants. Lancet, $1,871$.

LAW, T. J. AND HuLl, R. N. 1968. The stabilizing effect of sucrose upon respiratory syncytial virus infectivity. Proc. Soc. exp. Biol. Med., 128, 515.

Peacock, D. B. AND ClaRke, S. K. R. 1961. Respiratory syncytial virus in Britain. Lancet, $2,466$.

Stott, E. J., Bell, E. J., Eadie, M. B., Ross, C. A. C. AND Grist, N. R. 1967. A comparative virological study of children in hospital with respiratory and diarrhoeal illnesses. J. Hyg., Camb., 65, 9.

STURDY, P., MCQuillin, J. AND GARDNER, P. S. 1969. A comparative study of methods for the diagnosis of respiratory virus infections in childhood. J. Hyg., Camb., 67, 659.

Suto, T., Yano, N., Ikeda, M., Miyamoto, M., Takai, S., Shigeta, S., Hinuma, Y. and IsHIDA, N. 1965. Respiratory syncytial virus infection and its serologic epidemiology. Am. J. Epidem., 82, 211.

Young, B. J. AND MATthews, R. S. 1969. A comparison of HEp-2 cells and a continuous line of human amnion cells for the primary isolation of respiratory syncytial virus. J. med. Lab. Technol., 26, 93. 